\title{
Clinton's health care reforms
}

\author{
An unstoppable momentum for change
}

Understanding why the national debate about health care reform has captured centre stage in the United States is easy. It is because the stakes are enormous. President Bill Clinton has staked his political future and that of his party, the Democrats, on the success of this effort. If health reform legislation is enacted, then, presuming the economy does not go sour, Clinton's re-election is assured. An unusual combination of middle class insecurity over health insurance coverage and exploding costs presents him with a rare opportunity to restructure American health care; if he misses it then he and his party are headed for a long exile from the White House.

Americans look to the Republicans to guide them through dangerous times in international affairs and to the Democrats to manage matters of social welfare. With the end of communism, the nation has turned inward. A Democratic president whose party controls both branches of Congress but who cannot patch up and strengthen America's frayed health care net is a one term president.

To get the changes he wants the president and his administration will have to do battle with a vast army of vested interests. These include organised medicine, hospitals, institutions providing long term care, labour unions, large and small businesses, the pharmaceutical industry, universities, lawyers, nurses, and a bevy of bureaucrats who administer the current hotchpotch of federal, state, and local programmes such as Medicare for elderly people, Medicaid for poor people, and a myriad of others.

More than $\$ 900 \mathrm{bn}$ is at stake. This staggering sum constitutes one seventh of the United States' gross domestic product and is equal to the entire economy of Italy. The sheer amount of money at issue guarantees that every fax machine, cellular phone, public relations firm, and lobbyist located anywhere near Washington, DC, will be kept very busy during the current congressional term.

The administration is pushing "managed competition" as the way to extend coverage to all for a basic package of services while containing cost, as John Roberts discusses in detail in his news story (p 819). ${ }^{1}$ This mongrel is a compromise between those who believe that the market is the only proved mechanism for efficient distribution and those who believe that health care is a service that is not amenable to market forces. Much of the content of the debate that will now swirl in Congress will be over how competition in health care is to be "managed."

Clinton launched his campaign by invoking the values of security, simplicity, savings, choice, quality, and responsibility. In following this strategy he and his health care team, of which his wife, Hillary, is the most prominent member, consciously and quite deliberately took a page from the experience of Britain and Canada in creating universal health insurance schemes. The president hopes that by appealing explicitly to moral values he can build sufficient political consensus for change to overcome the considerable inertia that exists when those with their hands in a till filled with $\$ 900$ bn are asked to pull their hands back a bit.

The initial reaction to the proposal for health plans to compete for the dollars of those who want coverage under the watchful eye of a national health board and regional health alliances (somewhat akin to regional health authorities in the NHS) has been positive. Those on the left moped about the limits that Clinton placed on the minimum benefits package; no long term care, minimal mental health benefits, and uneven home care services were all bemoaned. But the prospect of the citizenry running around the countryside flashing a health security card is so enticing that, despite growls about the superiority of single payer schemes that completely eliminate private insurance, the left's eventual support for the administration's proposal is assured.

One would think that the Clinton proposal will find a less congenial home among those on the right. But big business is eager for relief from the constantly spiralling cost of health insurance premiums as most Americans get their health insurance through their jobs. With a tenth of the American population carrying no health insurance, mainly because they are self employed, work part time, or have recently become unemployed, doubts about the adequacy of paying for health care by means of fee for service care purchased through private insurance have percolated up through the middle and upper strata of society. And large insurance companies and managed care firms think that managed competition affords them the opportunity to force smaller firms to close and to seize more market share as they believe that economies of scale will allow them to provide the requisite package of services for lower fees.

Even American physicians, who have traditionally opposed any attempt by the government to infuse itself into health care, are strangely quiet. This is probably because a large and rapidly growing number of them no longer work in fee for service settings and they are frustrated at the amount of paperwork they must contend with to get reimbursement from the maze of third party payers that now exists. 
The president has gone out on a very precarious limb to find the consensus necessary to effect change. He has promised Americans that they can have more security and peace of mind about their health care coverage, including improved benefits and a higher quality of care, simply by wringing savings out of the fat of the current system. This has led to charges from some quarters that the president is trying to get something for nothing. That assessment is too harsh. But it is true that the president is trying to convince the American people to sit still for fairly nasty surgery by promising that it will not hurt very much.

How much pain the "haves" in the current system believe reform will bring will determine the fate of Clinton's plan. Small businesses are already yelling loudly that a mandate to cover workers will cost jobs and lots of them. Although the tobacco industry is not what it once was, it is still a force to be reckoned with in American politics, and big increases in vice taxes will not sit well with them or their concerned and ready to lobby cousins in the alcohol, gambling, and food industries. Advocates for elderly people and the very poor will vigorously protest if their current entitlement programmes are targeted for more than minimal cuts. And, as eager as many Americans are for lower costs, many will wince over the notion of capping of the rate at which insurance premiums for the basic or baseline package of health care services can rise-a strategy that some fear will deny them access to the next generation of medical technology and breakthroughs.

Once the euphoria over the fact that the nation has finally managed to talk seriously about doing something about its flawed health care system wears off, four large potholes are likely to emerge on the road to legislation. Coverage for abortions is in the president's basic package, and this will trigger yet another round of finger pointing and screaming as the entrenched sides on this issue fight it out yet again. Rural Americans and their congressional representatives are likely to become nervous about reform built on the concept of managed competition when they realise that it does not guarantee that any health care plans will want to compete for the limited business that rural customers represent. Those who oppose change will point out that there is a danger that health care plans under managed competition will meet their payrolls by rationing services. Any talk of rationing could dry up middle and upper class support for change. And it will not be long before insured Americans realise that they will probably be getting less choice of provider than many now have. In autonomy mad America, loss of choice is politically lethal.

Still, punters would be wise to bet on change. While derailment is possible, exploding costs are pushing the Clinton engine down the track with enough momentum that a bill will most likely be signed by next summer.

ART CAPLAN Director

Center for Biomedical Ethics,

University of Minnesota,

Minneapolis, MN, USA

1 Roberts J. Clinton's health reforms. BMf 1993;307:819-20.

\title{
Asthma: what is there left to find out?
}

\author{
Firstly, why and how do people become asthmatic?
}

Despite the many recent advances in our understanding of asthma many questions remain unanswered. ${ }^{1}$ Asthma has been rediscovered as an inflammatory disease, and the nature of the inflammatory reaction has been defined by applying modern immunohistological and molecular biological techniques to bronchial biopsy specimens and cells obtained by bronchoalveolar lavage. ${ }^{2}$ Inflammation is found even in patients with the mildest asthma and is characterised by infiltration of eosinophils and activation of mast cells, $T$ lymphocytes, and macrophages.

Activated inflammatory cells in asthmatic airways release a bewildering number of mediators, but the recent development of specific mediator antagonists has shed some light on their relative importance. Leukotriene D4 seems the most important mediator of bronchoconstriction, whereas various cytokines play a critical part in recruiting and activating inflammatory cells. ${ }^{34}$ In addition to bronchoconstriction, evidence exists for exudation of plasma, vasodilatation, hypersecretion of mucus, and activation of sensory nervesall contributing to the clinical features of asthma. Although acute inflammation has been emphasised, it is evident that asthma is a chronic inflammatory condition. Structural changes (subepithelial fibrosis, hyperplasia of airway smooth muscle, angiogenesis) may result, which may be irreversible.

So what uncertainties remain? The worldwide increases in morbidity caused by asthma and in mortality from the disease are largely unexplained. ${ }^{5}$ The origins of asthma are obscure. Although atopy is by far the most important risk factor for the development of asthma, what determines whether an atopic person becomes asthmatic is uncertain. Several possible causes have been considered, including exposure to inhaled allergens (particularly house dust mite), viral infections, passive cigarette smoking, and air pollution. A critical period may exist in early childhood when asthmatic inflammation becomes established.

Perhaps the greatest mystery is why the underlying abnormalities of asthma persist (in most patients forever). The inflammatory response becomes chronic, and, although it may be controlled with steroids, it almost always recurs when steroids are stopped. This is best illustrated in occupational asthma due to exposure to chemical sensitisers, such as toluene di-isocyanate. Removal from industrial exposure usually results in the complete resolution of asthma if exposure was for less than six months, but with exposure for longer than six months asthmatic inflammation persists even after complete and prolonged avoidance of exposure. ${ }^{6}$ This suggests that a mechanism exists for perpetuating the chronic inflammatory response even without a driving mechanism.

Recent observations on transplanted asthmatic lungs are instructive. Two non-asthmatic recipients of lungs obtained from known asthmatic donors developed features of asthma, with eosinophilic infiltration and the diurnal variation in airflow obstruction characteristic of asthma. ${ }^{7}$ This suggests that the mechanism for the persistence of asthma is present in the lungs, possibly in the form of a permanent population of memory $\mathrm{T}$ cells which can orchestrate the typical asthmatic inflammation. Eradicating these lymphocytes may even offer the possibility of a cure for asthma in the future. 